\title{
Shakespeare in Theory and Practice
}

\author{
JONATHAN LOCKE HART
}

\begin{abstract}
The article is about theory and practice in Shakespeare, but while he used the word "practice," he never employed the term "theory." After discussing practice a little, I shall examine how Shakespeare refers to poetry and poets, philosophy and philosophers with some brief connections with art, theatre, music, painting and mimesis. Shakespeare showed no inclination for criticism or theory in essays or non-fiction prose, but, as can be seen, for instance, in Hamlet's instructions to the players, his work, poetry and plays, contain if not a theory of art, theatre and poetry at least some representations of and reflections on such matters by speakers, narrators and characters.
\end{abstract}

Keywords: William Shakespeare; theory; practice; poetry; poets; philosophy; philosophers; art

Like James Joyce after him, Shakespeare showed no inclination for criticism or theory in essays or non-fiction prose, but, as can be seen, for instance, in Hamlet's instructions to the players, his work, poetry and plays, contain if not a theory of art, theatre and poetry at least some representations of and reflections on such matters by speakers, narrators and characters. How can one of the greatest writers in any genre - literature, philosophy or history - to mention the kinds of writings Aristotle discussed in Poetics - not write a theory of what he was doing in practice? This is not unusual as Homer, Aeschylus, Sophocles and Euripides did not seem to feel the need to theorize their art of poetry and drama. Aristophanes was able to use his art to explore mimesis and Horace wrote a poem about the art of poetry, so in classical antiquity writers could be interested in reflecting on their art directly or indirectly within their art (see Halliwell 1986; Hart 2013; Hart 2019). Later, writers such as Philip Sidney could write literature and criticism (theory), and in fact Sidney writes both at the highest level (see Sidney).

Shakespeare does not develop a coherent theory of poetry, theatre or art, but there are shards and fragments of what his speakers and characters (not the author) say about these matters. Any theoretical perspectives are not systematic and they are also fictional, that is within the fictions of poetry and drama. Shakespeare never uses "theory" or its cognates in any of his poems or 
plays. The noun "practice" and the verb "practise" do appear (the spelling is not fixed so one cannot determine verb or noun by spelling alone as in British English today). Rather than survey what are common uses of these two parts of speech relating to practice, something done over or a way of doing things or the verb to do over or make something happen, I shall focus on instances that have to do with art or something related to the nature of poetry and theatre. In Measure for Measure, Duke Vincentio opens the play with a speech that address Escalus, his wise counsellor (I.i.; all quotations and citations from Open Source Shakespeare). In part of that opening speech, Vincentio says:

The nature of our people,

Our city's institutions, and the terms

For common justice, you're as pregnant in

As art and practise hath enriched any

That we remember.

Escalus has the art and practice to know the nature of the people and institutions of Vienna. Vincentio ask Escalus what he thinks of Angelo, whom the duke has designated to rule in his absence, and Escalus approves of Angelo. Ironically, Angelo does not turn out to be the person portrayed, but a Puritan corrupted by lust.

Art and practice in Pericles are also connected in a speech of Cerimon, a lord of Ephesus. In III.ii. he tells the First Gentleman and the Second Gentleman:

'Tis known, I ever

Have studied physic, through which secret art,

By turning o'er authorities, I have,

Together with my practise, made familiar

1325

To me and to my aid the blest infusions

That dwell in vegetives, in metals, stones;

Art and practice are part of the alchemy or magic or "science" Cerimon describes. Shakespeare does not use "practice" as in the practice of poetry or drama or art, so although he uses this word and its cognates, he does not use it in a literary or theatrical way. In effect, Shakespeare does not mention the words "theory" or "theoretical" and does not really speak of practice as the practice of poetic and theatrical arts.

Perhaps the closest instances occur in two early plays. In III.ii. of Two Gentleman of Verona Thurio says he will "put in practice" the advice he has been given (line 1541). The wider context is one of poetry and art in matters of love: 
Duke of Milan. Ay,

Much is the force of heaven-bred poesy.

Proteus. Say that upon the altar of her beauty

You sacrifice your tears, your sighs, your heart:

Write till your ink be dry, and with your tears

Moist it again, and frame some feeling line

That may discover such integrity:

For Orpheus' lute was strung with poets' sinews,

Whose golden touch could soften steel and stones,

Make tigers tame and huge leviathans

Forsake unsounded deeps to dance on sands.

After your dire-lamenting elegies,

Visit by night your lady's chamber-window

With some sweet concert; to their instruments

Tune a deploring dump: the night's dead silence

Will well become such sweet-complaining grievance.

This, or else nothing, will inherit her.

Duke of Milan. This discipline shows thou hast been in love.

Thurio. And thy advice this night I'll put in practise.

Therefore, sweet Proteus, my direction-giver,

Let us into the city presently

To sort some gentlemen well skill'd in music.

I have a sonnet that will serve the turn

To give the onset to thy good advice.

Poesy is made in heaven and, however much this is a comic context of obedience and disobedience in love between the generations and of the parental block to the daughter and her real feelings and love, there is a sense that poetry can move people. Irony and levity occur in the descriptions of the beloved and the lover poet whose tears undry the ink of the love poetry he is writing. Orpheus' lute, in this extended description of poetry in images and metaphors, is strung with the sinews of poets, something one might wish to take metaphorically given the pain of such a proposition. The sad laments of elegies and the music of love songs like sonnets are part of the imagery Shakespeare gives to his characters: putting into practice in love the advice of how to deploy the poetic skills necessary to woo a beloved.

Representing this context of verbal art or words meant for an audience is a speech of Tranio, Lucentio's servant who in the opening scene of The Taming of the Shrew (I.i) speaks about the "practice of rhetoric" (line 328) amid the other liberal arts. In this scene, Shakespeare has master and servant discuss these studies. Lucentio speaks of seeing "fair Padua, nursery of arts" (line 295) and he suggests that Tranio and he "haply institute/ A course of learning and 
ingenious studies" (lines 301-302) and that he will "study,/ Virtue and that part of philosophy/ Will I apply that treats of happiness/ By virtue specially to be achiev'd." (lines 310-313). To which Tranio replies:

$\underline{\text { Tranio. }}$ Mi perdonato, gentle master mine;

I am in all affected as yourself;

Glad that you thus continue your resolve

To suck the sweets of sweet philosophy.

Only, good master, while we do admire

This virtue and this moral discipline,

Let's be no Stoics nor no stocks, I pray,

Or so devote to Aristotle's checks

As Ovid be an outcast quite abjur'd.

Balk logic with acquaintance that you have, And practise rhetoric in your common talk;

Music and poesy use to quicken you;

The mathematics and the metaphysics,

Fall to them as you find your stomach serves you.

No profit grows where is no pleasure ta'en;

In brief, sir, study what you most affect.

In essence, Tranio is arguing for pleasure and what one likes rather than the moral rigours of virtue and philosophers like the Stoics and Aristotle. He prefers a love poet, Ovid, to these philosophers. Tranio sums up that his master should study what he "affects." Pleasure precedes profit, which is a brief theory of learning. This passage also takes up the old conversation or quarrel between philosophy and poetry found in Plato, Aristotle, Philip Sidney and others but does so in a comic context, so the tone is closer to the satirical mood of Aristophanes (maybe thrown in with Plautus and Terence and the new comedy rather than the old comedy).

The comic take on philosophy can also be related to competition in love and to music:

Hortensio. But, wrangling pedant, this is

The patroness of heavenly harmony.

Then give me leave to have prerogative;

And when in music we have spent an hour,

Your lecture shall have leisure for as much.

Lucentio. Preposterous ass, that never read so far

To know the cause why music was ordain'd!

Was it not to refresh the mind of man

After his studies or his usual pain? 
Then give me leave to read philosophy,

And while I pause serve in your harmony.

Hortensio. Sirrah, I will not bear these braves of thine.

Bianca. Why, gentlemen, you do me double wrong

To strive for that which resteth in my choice.

I am no breeching scholar in the schools,

I'll not be tied to hours nor 'pointed times,

But learn my lessons as I please myself.

And to cut off all strife: here sit we down;

Take you your instrument, play you the whiles!

His lecture will be done ere you have tun'd.

Philosophy is one of the sources of literary theory, as can be observed in Plato and Aristotle, as they both discuss poetry, and so before proceeding to poetry and theatre, and what Shakespeare's speakers say about that, I shall examine what they say about philosophy and philosophers, theorists of a kind. In the opening scene of Love's Labour's Lost, Dumain, speaking of himself in the third person, says:

My loving lord, Dumain is mortified:

The grosser manner of these world's delights

He throws upon the gross world's baser slaves:

To love, to wealth, to pomp, I pine and die;

With all these living in philosophy.

Philosophy, as it was for Tranio in Taming, is, according to Dumain, opposed to the "delights" of the world. In comedy, however, often those given to cloistered lives or a stern philosophical view end up subject to love and the world around them. Denying the world in this play (Love's Labour's Lost) is not something the characters in the first scene succeed in doing as the play goes on. At III.ii. of As You Like It, a pastoral and romantic comedy, Touchstone, the clown, asks Corin:

Hast any philosophy in thee, shepherd?

Corin. No more but that I know the more one sickens the worse at ease he is; and that he that wants money, means, and content, is without three good friends; that the property of rain is to wet, and fire to burn; that good pasture makes fat sheep; and that a great cause of the night is lack of the sun; that he that hath learned no wit by nature nor art may complain of good breeding, or comes of a very dull kindred.

Touchstone. Such a one is a natural philosopher. 
The "philosophy" of Corin, the shepherd, is learned from the practical observation of nature and art in life. Although his response is comic and sometimes tautological and absurd (that rain is wet), Corin is, in some ways, as Touchstone is right to call him a "natural philosopher," someone who is by nature a philosopher or even a scientist (natural philosopher is the early term for that). Touchstone proceeds to ask Corin if he has ever been to court, which he says he has not. So the philosophy of nature comes to be contrasted with the artifice and foolishness of court. But the two characters get into a comic exchange of logic about the comparison of court and nature, so that the virtues of nature and the limitations of court and country are not treated too solemnly (lines 1150-1196). The practice of comedy is part of this practice of philosophy. In this play Shakespeare makes this comic and philosophical nexus but does through characters for the audience (later sometimes the reader). There is no one authorial voice or position.

In another "comic" play, Troilus and Cressida, philosophy enters the debate among the Trojans over the Greek ultimatum about Helen. Priam asks for advice. Hector would return her, his brother, Troilus, would not. Cassandra prophesies: "Cry, Trojans, cry! a Helen and a woe:/ Cry, cry! Troy burns, or else let Helen go" (lines 1106-1107). Paris would keep here. Hector brings in philosophy in his deliberations in response to Priam's request for advice:

Paris and Troilus, you have both said well,

And on the cause and question now in hand

Have glozed, but superficially: not much

Unlike young men, whom Aristotle thought

Unfit to hear moral philosophy:

1165

The reasons you allege do more conduce

To the hot passion of distemper' $d$ blood

Than to make up a free determination

'Twixt right and wrong, for pleasure and revenge

Have ears more deaf than adders to the voice

Of any true decision. Nature craves

All dues be render'd to their owners: now,

What nearer debt in all humanity

Than wife is to the husband? If this law

Of nature be corrupted through affection,

And that great minds, of partial indulgence

To their benumbed wills, resist the same,

There is a law in each well-order'd nation

To curb those raging appetites that are 
HART

Most disobedient and refractory.

If Helen then be wife to Sparta's king,

As it is known she is, these moral laws

Of nature and of nations speak aloud

To have her back return'd: thus to persist

In doing wrong extenuates not wrong,

But makes it much more heavy. Hector's opinion

Is this in way of truth; yet ne'ertheless,

My spritely brethren, I propend to you

In resolution to keep Helen still,

For'tis a cause that hath no mean dependance

1190

Upon our joint and several dignities.

Hector uses reason and considers his brothers Paris and Troilus, to have been superficial in their interpretations. Moreover, Hector appeals to Aristotle, who thought young men were not fit to hear moral philosophy. Hector thinks that his brothers are too caught up in passion. He reasons that the moral law means that Helen should be returned to the king of Sparta, her husband, but then surprisingly says that Helen should stay because her cause depends of the several dignities of the Trojan royal family. Thus, Hector appeals to philosophy and reason, but all that leads nowhere except, in practice, to keep Helen at Troy as the dignity of the occasion requires that. Moral truth yields to customary values. The theory calls for one thing, but the practice delivers the opposite.

In the histories, the matter of gender arises. In the middle of King John - III. iv - Shakespeare introduces "philosophy" into the dialogue. When Cardinal Pandulph says, "Lady, you utter madness, and not sorrow," Constance answers:

Thou art not holy to belie me so;

I am not mad: this hair I tear is mine;

My name is Constance; I was Geffrey's wife;

Young Arthur is my son, and he is lost:

I am not mad: I would to heaven I were!

For then, 'tis like I should forget myself:

$\mathrm{O}$, if I could, what grief should I forget!

Preach some philosophy to make me mad,

And thou shalt be canonized, cardinal;

For being not mad but sensible of grief,

My reasonable part produces reason

How I may be deliver'd of these woes,

And teaches me to kill or hang myself:

If I were mad, I should forget my son, 
Or madly think a babe of clouts were he:

I am not mad; too well, too well I feel

The different plague of each calamity.

Constance responds that she is not mad but someone who could forget herself were she mad. Rather surprisingly, she asks the cardinal to preach some philosophy to make her mad, as one might think philosophy is a matter of reason, so perhaps she is being ironic because the cardinal mistakenly called her mad and she says he will be canonized if he can make her mad with philosophy. She says that she is reasonable and feels grief because of it and that if she were mad, she would not experience the loss of her son. Her reason seems to tell her to kill herself to deliver herself from these woes, but alas she is not mad and thus feels "each calamity." Here is a woman who denies a man who cannot have a son because he is a priest (or is not supposed to) so he cannot feel her pain at the loss of her son, and she stands up to him with logic, in front of other aristocratic men (she is the mother of the duke of Brittany - Bretagne) and plays on "philosophy" and contrasts reason and madness.

In the tragic mode, Shakespeare also alludes to philosophy. The theory and practice of philosophy - its precepts can help with how to love and the experience of life itself - are matters Shakespeare represents across genres. In modern Italy, Shakespeare locates philosophy in the centre of Romeo and Juliet in a discussion of Romeo's "banishment":

Friar Laurence. I'll give thee armour to keep off that word:

1925

Adversity's sweet milk, philosophy,

To comfort thee, though thou art banished.

Romeo. Yet 'banished'? Hang up philosophy!

Unless philosophy can make a Juliet,

Displant a town, reverse a prince's doom,

It helps not, it prevails not: talk no more.

1930

For Friar Laurence, philosophy is a comfort and consolation, something that arms one against adversity, but for Romeo, philosophy is not helpful in consoling him about being banished unless it "can make a Juliet," change geography and the prince's decision to banish him. If philosophy is something in theory and not in practice, then there is no point talking any more in Romeo's estimation. The character, this boy or young man, expects something that can affect his experience and not some abstract rule to live by.

Later in ancient Rome, Shakespeare explores this theme of the philosophical. In IV.iii of Julius Caesar the matter comes up at a time of crisis: 
Brutus. O Cassius, I am sick of many griefs.

Cassius. Of your philosophy you make no use,

If you give place to accidental evils.

Brutus. No man bears sorrow better. Portia is dead.

2145

This use of philosophy here is a kind of Stoicism that does not allow the accidents of life to take over. Brutus, however, responds to Cassius that he is dealing with his wife's death and actual suicide. For Brutus, his private and public lives are crumbling and in time he takes his own life too in search of Roman honour. In V.i, Cassius and Brutus have another exchange before they venture into battle:

Cassius. Now, most noble Brutus,

The gods to-day stand friendly, that we may,

Lovers in peace, lead on our days to age!

But since the affairs of men rest still incertain,

Let's reason with the worst that may befall.

If we do lose this battle, then is this

The very last time we shall speak together:

What are you then determined to do?

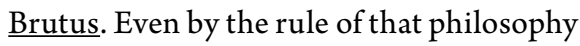

By which I did blame Cato for the death

Which he did give himself, I know not how,

But I do find it cowardly and vile,

For fear of what might fall, so to prevent

The time of life: arming myself with patience

To stay the providence of some high powers

That govern us below.

Cassius. Then, if we lose this battle,

You are contented to be led in triumph

Thorough the streets of Rome?

Brutus. No, Cassius, no: think not, thou noble Roman,

That ever Brutus will go bound to Rome;

He bears too great a mind.

Even though Brutus criticized Cato the Younger, a Stoic, for committing suicide rather than submitting to Julius Caesar or being led in triumph in Rome, Brutus himself chooses the same thing. Brutus is a "noble Roman" and "too great a mind" to "go bound to Rome." Cato was Brutus' father in law and Brutus' dead wife Portia Cato's daughter: both father and daughter committed suicide. Whereas Hector argues for philosophy but decides against it, Brutus chides philosophy but chooses it. 
A certain ambivalence over philosophy occurs in Denmark. In I.v. of Hamlet, the natural and supernatural meet:

Father's Ghost. [beneath] Swear by his sword.

Hamlet. Well said, old mole! Canst work i' th' earth so fast?

A worthy pioner! Once more remove, good friends.

Horatio. $\mathrm{O}$ day and night, but this is wondrous strange!

Hamlet. And therefore as a stranger give it welcome.

There are more things in heaven and earth, Horatio,

Than are dreamt of in your philosophy.

In encountering the Ghost, Hamlet wants to call attention to the limitation of Horatio's response and philosophy. The philosophical is not enough. Not even its dreams come close to what is in heaven and earth. Yet soon after, at II.i, Hamlet appeals to philosophy in a conversation with Rosencrantz and Guildenstern about the players and related matters:

Hamlet. It is not very strange; for my uncle is King of Denmark, and those that would make mows at him while my father lived give twenty, forty, fifty, a hundred ducats apiece for his picture in little. 'Sblood, there is something in this more than natural, if philosophy could find it out.

Hamlet wryly comments on how others want Claudius' picture now that he is king, the same ones who would not want that while Hamlet Senior was king and he wishes to see whether philosophy could find something more than natural in this matter. The prince seems to see philosophy as being possible too but also implies its limitation. He has not yet found out the answer to this question.

The figure of the philosopher is also something Shakespeare represents in his plays. What the characters say about philosophers is also varied. The comedies use the term "philosopher" in a few places. As we saw at III.ii of $A s$ You Like It, Touchstone employs the word with the shepherd (line 1150). Later at V.i, Touchstone says to William:

Why, thou say'st well. I do now remember a saying: 'The fool doth think he is wise, but the wise man knows himself to be a fool.' The heathen philosopher, when he had a desire to eat a grape, would open his lips when he put it into his mouth; meaning 2220 thereby that grapes were made to eat and lips to open. You do love this maid? 
HART

As Touchstone had with the shepherd, he plays with logic and wit with William and goes on to speak about a figure of rhetoric in terms of drink and to construct syllogisms of sense and nonsense. The figure of the wise man and the fool runs through this play and is not uncommon in Shakespeare, for instance in King Lear. It echoes Saint Paul in Corinthians, for instance: "We are fools for Christ's sake, and ye are wise in Christ (Geneva Bible, Corinthians, 4:10) and also has a theological echo in an elaboration of foolishness and wisdom as developed by two Dutch clergy, Thomas à Kempis and Erasmus, the first Latin text The Imitation of Christ and the second Latin The Praise of Folly. In this first text, for example, Thomas says, " 5 Thou must be contented to be esteemed a foole for the love of Christ, if thou wilt lead a religious and Christian life" and "29 Then will it appeare that he was wise in this world, who had lear|ned for Christ to be a foole and despi|sed" (Kempis 40, 74). Erasmus has Folly speak an encomium and she goes back to Paul:

And so at last I return to Paul. "Ye willingly," says he, "suffer my foolishness," and again, "Take me as a fool," and further, "I speak it not after the Lord, but as it were foolishly," and in another place, "We are fools for Christ's sake." You have heard from how great an author how great praises of folly; and to what other end, but that without doubt he looked upon it as that one thing both necessary and profitable. "If anyone among ye," says he, "seem to be wise, let him be a fool that he may be wise." And in Luke, Jesus called those two disciples with whom he joined himself upon the way, "fools." Nor can I give you any reason why it should seem so strange when Saint Paul imputes a kind of folly even to God himself. "The foolishness of God," says he, "is wiser than men." Though yet I must confess that origin upon the place denies that this foolishness may be resembled to the uncertain judgment of men; of which kind is, that "the preaching of the cross is to them that perish foolishness." (Erasmus 1668)

Here, I gesture to a Christian philosophy that was part of Shakespeare's context and even in comedy there might well be a seriousness in jest that is not solemn but serious none the less. Shakespeare mixes the classical and the Christian. There is a comic surface but also a possible allusory depth.

At I. ii of Merchant of Venice, Portia speaks to Nerissa about suitors and does not like them, for instance the Neapolitan prince and the County Palatine:

He doth nothing but frown, as who should say 'If you

will not have me, choose:' he hears merry tales and

smiles not: I fear he will prove the weeping

philosopher when he grows old, being so full of 
unmannerly sadness in his youth. I had rather be married to a death's-head with a bone in his mouth than to either of these. God defend me from these two!

Although Portia will speak of the quality of justice, she is not interested in these two men, the second being like a sad philosopher, and she would "rather be married to a death's-head with a bone in his mouth" as if they were not as full of life as death itself chewing on bones. Philosophy is sad and deadening here in the figure of this philosopher and the other suitor.

Leonato speaks about philosophy to Antonio in V.i of Much Ado About Nothing and once more there is an element of theory and practice, the abstract and concrete in the matter:

I pray thee, peace. I will be flesh and blood;

For there was never yet philosopher

That could endure the toothache patiently,

However they have writ the style of gods

2105

And made a push at chance and sufferance.

In life a philosopher cannot endure pain no matter how divine his style. There is a gap between the theory of reality and reality itself. Putting theory into practice, is according to Leonato, something not possible. Pain trumps ideas.

In King Lear, as we saw before, Lear, who seems mad, talks with Kent, Gloucester and Yom o'Bedlam in the storm (III.iv) and asks Tom (Edgar) who feigns madness - this "philosopher," what is the cause of thunder (lines 1946-1947). Later in the scene Lear continues to address Tom in a similar way: "O, cry you mercy, sir./ Noble philosopher, your company" (lines 19651966). The Fool had been a wise man the king did not heed, and here Lear turns to a beggar who is actually Edgar, as the audience knows, but no one else, including his father Gloucester, knows. Kent and Gloucester humour Lear as they try to get him in from the elements:

Lear. With him!

I will keep still with my philosopher.

Earl of Kent. Good my lord, soothe him; let him take the fellow.

Earl of Gloucester. Take him you on.

Earl of Kent. Sirrah, come on; go along with us.

1975

Lear. Come, good Athenian.

Earl of Gloucester. No words, no words! hush. 
So this noble son of Gloucester pretending to be a mad beggar is, for the mad king, who knows none of this, a "noble philosopher," an Athenian, of the home of philosophy. The philosopher is a figure of irony for Lear, Kent and Gloucester, who, unlike the audience, do not know the difference between appearance and reality - Tom and Edgar.

Timon of Athens, another tragedy probably written about the same time or a little later than King Lear, actually has a philosopher, Apemantus in the play, and the opening scene includes a poet and a painter, him and others. At one point in the scene, friction occurs between poet and philosopher:

Timon. How dost thou like this jewel, Apemantus?

Apemantus. Not so well as plain-dealing, which will not cost a man a doit.

Timon. What dost thou think'tis worth?

Apemantus. Not worth my thinking. How now, poet!

Poet. How now, philosopher!

Apemantus. Thou liest.

Poet. Art not one?

Apemantus. Yes.

Poet. Then I lie not.

Apemantus. Art not a poet?

Poet. Yes.

Apemantus. Then thou liest: look in thy last work, where thou hast feigned him a worthy fellow.

Poet. That's not feigned; he is so.

The theme of truth and lies, the quarrel found in Plato between philosophy and poetry, occurs here in a kind of cranky comedy, even if the play is a tragedy. Feigning and how things are becomes a crux in this scene. In II.ii Apemantus, the philosopher, speaks with the Fool, who speaks of a spirit that appears like a lord, or lawyer or philosopher (lines 790-796). Later in the scene, when Apemantus bids the Fool to come with him, the Fool responds: "I do not always follow lover, elder brother and woman; sometime the philosopher" (lines 804805). Once more, Shakespeare represents the fool and the wise person, not simply something dramatic but also something that the classical and Christian traditions had explored.

The ambivalence over philosophy and philosophers cuts across genres in Shakespeare. Lafeu's speech at II. iii in All's Well That Ends Well embodies the tension between ancient ways and religion and new ways and philosophy: 
Lafeu. They say miracles are past; and we have our philosophical persons, to make modern and familiar, things supernatural and causeless. Hence is it that we make trifles of terrors, ensconcing ourselves into seeming knowledge, when we should submit 895 ourselves to an unknown fear.

Parolles. Why, 'tis the rarest argument of wonder that hath shot out in our latter times.

Bertram. And so 'tis.

Lafeu. To be relinquish'd of the artists, 900

Parolles. So I say.

Lafeu. Both of Galen and Paracelsus.

Parolles. So I say.

Lafeu. Of all the learned and authentic fellows,-

Parolles. Right; so I say.

Shakespeare is above all a dramatist so when he represents history, philosophy or history, he does so with an eye to dramatic tension and interest. The situation is that Lafeu is an old lord and it may be that philosophy, for him, represents a new way, which may be threatening. Parolles makes light and even satirizes this view of "wonder." He also provides a comic chorus "So say I" or a close variant. Philosophy has a dramatic and comic dimension here and is not something that can be separated from the dramatic texture itself. Indeed, in all of Shakespeare, theory and philosophy, or anything else, cannot be taken out of context and made simply in terms of content without form or art.

Poetry, as well as philosophy, is part of the world of the plays. The comedies include allusions to poetry. In Taming of the Shrew and Love's Labour's Lost, poetry is related to schoolmasters and education. In the opening scene of the former play, Baptista Minola, a gentleman, says:

Gentlemen, content ye; I am resolv'd.

Go in, Bianca. Exit BIANCA.

And for I know she taketh most delight

In music, instruments, and poetry,

Schoolmasters will I keep within my house

Fit to instruct her youth.

Poetry and music become part of the young woman's education. In the next scene (II.ii), Gremio tells Hortensio something that reinforces what was said in the passage I quoted above: 
To Baptista Minola.

I promis'd to enquire carefully

About a schoolmaster for the fair Bianca;

And by good fortune I have lighted well

On this young man; for learning and behaviour

Fit for her turn, well read in poetry

And other books - good ones, I warrant ye.

Study is taken here, by Baptista Minola, to include poetry, something reported by Gremio in poetry. Shakespeare practises poetry and gives poetry to his characters as they discuss poetry. In Love's Labour's Lost (IV.ii), Holofernes, a schoolmaster, talks with Sir Nathaniel about dining at the house of the father of a pupil and Holofernes "will prove those verses to be very unlearned, neither savouring of poetry, wit, nor invention" (lines 1306-1308). How poetic and how pedantic is the schoolmaster?

In As You Like It, in the middle of the play (III.iii), Touchstone continues in his clownish wit, this time in regard to poetry, and in an exchange with Audrey, a woman from the country:

Touchstone. I am here with thee and thy goats, as the most capricious poet, honest Ovid, was among the Goths.

Jaques (lord). [Aside] O knowledge ill-inhabited, worse than Jove in a thatch'd house!

Touchstone. When a man's verses cannot be understood, nor a man's good wit seconded with the forward child understanding, it strikes a man more dead than a great reckoning in a little room. Truly, I would the gods had made thee poetical.

Audrey. I do not know what 'poetical' is. Is it honest in deed and word? Is it a true thing?

Touchstone. No, truly; for the truest poetry is the most feigning, and lovers are given to poetry; and what they swear in poetry may be said as lovers they do feign.

Audrey. Do you wish, then, that the gods had made me poetical? Touchstone. I do, truly, for thou swear'st to me thou art honest; now, if thou wert a poet, I might have some hope thou didst feign.

Jacques, in an aside, comments on Touchstone's abuse of knowledge. The clown would play with the country girl with his foolish logic, in that poetry is feigning and if she were like a poet then how honest could she be because she would be feigning, and since his intentions may not be the best, Touchstone would hope that she was not honest but feigning like a poet. She admits not to know 
much about being a poet or poetical. Shakespeare, then, has three characters with different views in an exchange that represents the nature of poetry. Thus, the playwright plays on poetry in his dramatic poetry and his theatre but does not present a theory of poetry. It is feigning, as the best poets are for Touchstone, but Audrey knows nothing about poetry and Jacques is sceptical about anything that Touchstone knows in this regard. Touchstone's view is that the truest poetry is the most feigning (he sounds like Oscar Wilde here) and that lovers are given to poetry and so feign when they swear their love.

In the middle of civil strife in the English histories, at III.i. of 1 Henry IV, Shakespeare presents a dramatic conflict between two rebels, the English lord, Henry Percy or Hotspur, and Owen Glendower, a Welsh lord, the one a practical soldier and other a kind of Celtic warrior-bard:

Glendower. I can speak English, lord, as well as you;

1665

For I was train'd up in the English court;

Where, being but young, I framed to the harp

Many an English ditty lovely well

And gave the tongue a helpful ornament,

A virtue that was never seen in you.

1670

Hotspur (Henry Percy). Marry,

And I am glad of it with all my heart:

I had rather be a kitten and cry mew

Than one of these same metre ballad-mongers;

I had rather hear a brazen canstick turn'd,

Or a dry wheel grate on the axle-tree;

And that would set my teeth nothing on edge,

Nothing so much as mincing poetry:

'Tis like the forced gait of a shuffling nag.

For Hotspur, the poetry of these ballads, which Glendower likes, is mincing. Shakespeare gives his characters their own brands of poetry, distinctive but equally marvellous and the irony here is that Hotspur's very concrete antipoetry is poetic, the images conveying in poetry why he does not like the kind of poetry he is satirizing and denying. The grating noises of poetry are amplified in Shakespeare's poetic form.

The word "poet" also occurs in Shakespeare's canon. In sonnet 17, the speaker represents the poet and the friend or beloved:

Who will believe my verse in time to come,

If it were fill' $\mathrm{d}$ with your most high deserts?

Though yet, heaven knows, it is but as a tomb 
Which hides your life and shows not half your parts.

If I could write the beauty of your eyes

And in fresh numbers number all your graces,

The age to come would say 'This poet lies:

Such heavenly touches ne'er touch'd earthly faces.'

So should my papers yellow'd with their age

Be scorn'd like old men of less truth than tongue,

And your true rights be term' $d$ a poet's rage

And stretched metre of an antique song:

But were some child of yours alive that time,

You should live twice; in it and in my rhyme.

Here, Shakespeare's speaker gives an extended image or metaphor of the poet representing the beauty and graces of the person addressed - the poem is a tomb hiding the life and half the parts of the addressee, so that others might think that the poet was lying or raging. Still, as in the generation sonnets at the beginning of Shakespeare's sonnet sequence, in which the speaker-poet encourages the beloved/friend to have a child, in this sonnet, in the final couplet, he says that if a child of the friend be alive at that time, the beloved or addressee should be alive twice - in the poem and in the child. The conceit of the poet is that he should not have any conceit, but that the friend is so worthy and should have a child and in that child, along with the poem, he should live. That is the "rhyme" of "time." The image of the poet will be as someone who enables that and not to be thought of in an age to come as a garrulous old man less given to truth than to lies. The old tension in poetry between truth and lies, so much explored by Plato, resurfaces here and elsewhere.

In sonnet 79 , Shakespeare has the poet-speaker speak of himself as a poet trying to make words about the beloved or friend (the addressee):

Whilst I alone did call upon thy aid, My verse alone had all thy gentle grace,

But now my gracious numbers are decay'd

And my sick Muse doth give another place.

I grant, sweet love, thy lovely argument

Deserves the travail of a worthier pen,

Yet what of thee thy poet doth invent

He robs thee of and pays it thee again.

He lends thee virtue and he stole that word

From thy behavior; beauty doth he give

And found it in thy cheek; he can afford

No praise to thee but what in thee doth live. 
Then thank him not for that which he doth say,

Since what he owes thee thou thyself dost pay.

The aid of the addressee or beloved-friend gave "gentle grace to the poem. Once he lost that aid, his verse decayed and his Muse grew sick. Thus, the poet says that the "sweet love" deserves "a worthier pen." Even another poet might fall short. In a sense, the speaker seems to be saying that he or any other poet is taking his praise of the beloved from this friend and not adding to it, just setting it out and giving it back, robbing him to pay him back with what was stolen from the "sweet love" or beloved. Shakespeare likes amplification or elaboration, and this happens over and over in his sonnets, one image building on the next, or one image being extended even farther. This hypothetical poet steals "virtue" from the beloved's behaviour, gives him beauty he took from the addressee's cheek. The poet only praises what lives in the beloved. Thus, this putative poet says what the beloved pays, so Shakespeare's poet, after belittling his own decaying and sick poetry, uses his poetic art to create another poet to write the praises of the beloved, only to undermine that poet for not being up to the task and really making his poetry by stealing what lives in the beloved himself. This poetry is about poetry, a kind of metapoetry or metapoetics.

Owing to space, I shall say a few more things about poets then even fewer words about theatre and painting. The comedies represent poets in various ways. In IV.iii of Love's Labour's Lost, Biron does not think that cutting oneself off from the world and especially women to study is a good idea. He says: For where is any author in the world/ Teaches such beauty as a woman's eye?" (lines 1657-1658). He connects love and the poet:

And when Love speaks, the voice of all the gods

Makes heaven drowsy with the harmony.

1690

Never durst poet touch a pen to write

Until his ink were temper'd with Love's sighs;

$\mathrm{O}$, then his lines would ravish savage ears

And plant in tyrants mild humility.

For Biron, poetry is a divine voice, harmonious, tempered with the sighs of love, ravishing savage ears, making tyrants humble. The beautiful, just and true are in poetry as it moves people. This is also the view of Philip Sidney.

At V.i of A Midsummer's Night's Dream, Theseus comments on poets in the company of lunatics and lovers, both frantic, when he responds to Hippolyta when she speaks about the strange things the lovers talk about: "The lunatic, the lover and the poet/ Are of imagination all compact (lines 1837-1838). 
HART

Imagination is the common denominator. The poet's art also has a certain franticness:

The poet's eye, in fine frenzy rolling,

Doth glance from heaven to earth, from earth to heaven;

And as imagination bodies forth

The forms of things unknown, the poet's pen

Turns them to shapes and gives to airy nothing

A local habitation and a name.

For Theseus, poets use imagination to take nothing and give it a being, a geography, an inhabiting, an identity, a nomination in the world. Poets make a name for others and not just themselves. They create worlds of others for others.

In V.i of Merchant of Venice, Lorenzo responds to Jessica's observation that she is never merrier than when she hears "sweet music" in a way that relates music moving wild and young colts until

Their savage eyes turn'd to a modest gaze

By the sweet power of music: therefore the poet

Did feign that Orpheus drew trees, stones and floods;

Since nought so stockish, hard and full of rage,

But music for the time doth change his nature.

The man that hath no music in himself,

Nor is not moved with concord of sweet sounds,

Is fit for treasons, stratagems and spoils;

The motions of his spirit are dull as night

And his affections dark as Erebus:

Let no such man be trusted. Mark the music.

Poets are like Orpheus and can change nature and, by implication, poetry is like music, which moves and transforms people and a man without music misses the concord and "Is fit for treasons, stratagems and spoils." Like Philip Sidney, Lorenzo sees poetry as moving others to virtue, and in this way it resembles music. A life or world without music and poetry is given to division, plots and unwarranted gain. A man without music (and by extension poetry) is not to "be trusted." Poetry and music have practical benefits in nature, for animal and human. Poets can also have a lighter side as we saw in Touchstone's two allusions to the poet in his exchange with Audrey in III.iii of As You Like It.

In Henry $V$, a history, there is a serious comic exchange - a heated difference - at III.vi between Pistol and Fluellen over the Exeter condemning 
Shakespeare in Theory and Practice

Bardolph to death for stealing a pax during the war. Pistol and Fluellen both speak of Fortune and Fluellen says:

By your patience, Aunchient Pistol. Fortune is painted blind, with a muffler afore her eyes, to signify to you that Fortune is blind; and she is painted also with a wheel, to signify to you, which is the moral of it, that she is turning, and 1495 inconstant, and mutability, and variation: and her foot, look you, is fixed upon a spherical stone, which rolls, and rolls, and rolls: in good truth, the poet makes a most excellent description of it: Fortune is an excellent moral.

Fluellen glosses or interprets the figure of Fortune: he points a moral based on the poet's description. Shakespeare has a character refer to another poet as Shakespeare, the dramatic poet, is presenting all this on Fortune, including the conflict between Pistol and Fluellen over the fate or fortune of Bardolph. This is another instance of metapoetics. The poet represents in words the words of another poet. Shakespeare attributes to characters uses of the word 'poet."

The tragedies also represent allusions to the poet. At IV.i of the eponymous play, Titus Andronicus says to his daughter Lavinia:

Lavinia, wert thou thus surprised, sweet girl,

Ravish'd and wrong'd, as Philomela was,

Forced in the ruthless, vast, and gloomy woods? See, see!

Ay, such a place there is, where we did hunt -

$\mathrm{O}$, had we never, never hunted there! -

Pattern'd by that the poet here describes,

By nature made for murders and for rapes.

At this moment after the rape and one of grief, Titus turns to the poet, to poetry and art, to make sense of the violence and the trauma Lavinia has suffered - his regret. He then turns to the story of Lucrece and tells how Tarquin had left the camp to "sin" in her bed, a story Shakespeare himself represents in The Rape of Lucrece. Titus' allusion to the poet may be to Ovid, but may also in the speech after this one be to Shakespeare himself, who told about the violation of Lucrece.

In Julius Caesar (III.iii), Cinna the Poet had a dream and thinks he should not go outdoors but does so only to find citizens who question him, mistake him for Cinna the conspirator and want to tear him to pieces anyway: 
Fourth Citizen. Tear him for his bad verses, tear him for his bad verses.

Cinna the Poet. I am not Cinna the conspirator.

Fourth Citizen. It is no matter, his name's Cinna; pluck but his name out of his heart, and turn him going.

Third Citizen. Tear him, tear him! Come, brands ho! fire-brands: 1855

to Brutus', to Cassius'; burn all: some to Decius'

house, and some to Casca's; some to Ligarius': away, go!

At this critical time in a tragedy, in which the citizens are reacting to Mark Antony's call against those who murdered Caesar, Shakespeare represents a poet among the mob and in the face of politics. Mistaken identity, illogic, mob mentality all are here at the heart of the play. In IV.iii, the character called the Poet wants to barge into Brutus' tent because Cassius and Brutus are quarrelling:

Poet. For shame, you generals! what do you mean?

Love, and be friends, as two such men should be;

For I have seen more years, I'm sure, than ye.

Cassius. Ha, ha! how vilely doth this cynic rhyme!

Brutus. Get you hence, sirrah; saucy fellow, hence!

Cassius. Bear with him, Brutus; 'tis his fashion.

Brutus. I'll know his humour, when he knows his time:

What should the wars do with these jigging fools?

Companion, hence!

Cassius. Away, away, be gone.

The Poet tries for peace and harmony between the generals, but Cassius mocks his "Cynic rhyme" and to Brutus is the Poet a "jiggling" fool. Both appearances of a poet show that poets are in the shadow of violence, war and politics and can suffer physical harm, death or mockery. Shakespeare, the dramatic poet, represents war and politics but has cameo roles for two poets, the poetry within the poetry. The metapoetics may also suggest, even in jest, that Shakespeare, too, is vulnerable by entering into war and politics.

In II.ii of Hamlet, the prince and Rosencrantz discuss the players, so that the question of acting and writing comes up:

Hamlet. What, are they children? Who maintains 'em? How are they escoted? Will they pursue the quality no longer than they can sing? Will they not say afterwards, if they should grow themselves to common players (as it is most like, if their means 
are no better), their writers do them wrong to make them exclaim against their own succession.

Rosencrantz. Faith, there has been much to do on both sides; and the nation holds it no sin to tarre them to controversy. There was, for a while, no money bid for argument unless the poet and the player $\quad 1440$ went to cuffs in the question.

The poet and actors become part of Hamlet's testing of the king and the matter of succession. Art once more becomes part of tensions among the rulers or politicians. Actors and poets are marginal beside princes and generals, but somehow Shakespeare inserts them at the heart of Rome and Denmark at critical moment. The poet - the dramatic poet - represents the poet or others talking about poets or speaking poetry - not simply the players, but Hamlet and Rosencrantz, who are creations in these words of Shakespeare.

Finally, as we have seen in Timon of Athens, the Painter, Poet, Jeweller and others are in the opening scene, and there, Apemantus, the philosopher, engages with the poet. In V.i. Timon watches the poet and painter from his cave. In that scene, Timon deals with the Painter and the Poet:

Hence, pack! there's gold; you came for gold, ye slaves:

[To Painter]

You have work'd for me; there's payment for you: hence!

[To Poet]

You are an alchemist; make gold of that.

2385

Out, rascal dogs!

Both artists exasperate Timon and he drives them out, the poet being an alchemist in his mind. Art here is not some innocent and magical endeavour, but something Timon, for better or worse, expunges. It is about money here, a practice, and not some abstract and theoretical work.

There is not enough space to examine music, painting and the theatre. I have discussed these matters elsewhere. Twelfth Night begins with the lines, "If music be the food of love, play on." It is the premise of the play. The painting in the ekphrasis in The Rape of Lucrece, as we also saw, is key to the poem, and music and painting are throughout Shakespeare. York's speech "As in a theatre" in Richard II about the king in London, Falstaff's acting with Hal in the tavern scene at II.iv of I Henry IV, the Chorus to Henry $V$ and Hamlet's instructions to the players and "The Mousetrap," the play within a play, all call attention to the theatre in what Lionel Abel called metatheatre and James Calderwood termed metadrama (see Abel 1963; Calderwood 1971). So although Shakespeare did 
HART

not write a treatise on the theory and practice of poetry, of theatre and the arts, the poems and plays are full of reflections by speakers and characters on theory and practice, on philosophy, philosophers, poetry and poets. Thus, even though Shakespeare does not use "theory" or its cognates in his work and often employs practice in ways that have little to do with poetic or theatrical practice, he does talk about philosophy and poetry and their practitioners, through his speakers and characters, in a variety of views. These views have to do with good poetry and drama and are not a treatise. The various points of view are part of the success of Shakespeare's art: he never set out to explore theory and practice, but he represents related matters in such a way to be of interest and to be suggestive about the theory and practice of poetry as they relate to philosophy, theatre, music, painting and the arts in general.

\author{
Jonathan Locke Hart \\ jonathan.hart@utoronto.ca, jonathan.hart@harvard.edu \\ University of Toronto/Harvard University \\ c/o Interlitteraria \\ Ülikooli 16-113 \\ 51003 Tartu \\ EESTI / ESTONIA
}

\title{
Bibliography
}

Abel, L. 1963. Metatheatre: A New View of Dramatic Form. New York: Hill and Wang. Aristotle / Longinus / Demetrius. 1932. The Poetics / On the Sublime / On Style. Transl. by W. Hamilton Fyfe (Aristotle) and W. Rhys Roberts. London: William Heinemann.

Calderwood, J. L. 1971. Shakespearean Metadrama. Minneapolis: University of Minnesota Press.

Erasmus, Desiderius. 1668. The Praise of Folly. Transl. by J. Wilson, http://www. gutenberg.org/files/9371/9371-h/9371-h.htm (13.03.2019).

Halliwell, S. 1986. Aristotle's Poetics. London: Duckworth.

Hart, J. 2013. Textual Imitation: Making and Seeing in Literature. New York: Palgrave. Hart, J. 2019. Making and Seeing Modern Texts, New York: Routledge.

Kempis, Thomas à. 1639. The imitation of Christ divided into four books / written in Latin by Thomas à Kempis; and the translations of it corrected \& amended by W.P. Oxford: Printed by Leonard Lichfield for Edw. Forrest, https://quod.lib.umich. edu/e/eebo/A13699.0001.001?view=toc (13.03.2019).

Shakespeare, W. Open Source Shakespeare, https://www.opensourceshakespeare.org/ (13.03.2019). 
Shakespeare in Theory and Practice

Sidney, Ph. 1595. The Defence of Poesie. Renascence Edition. University of Oregon. Transcribed and converted by Risa S. Bear, 1992, 1995. [“This etext of Philip Sidney (s Defence of Poesie is based on the Scolar Press facsimile of the British Museum's copy (Shelf-mark: C.57.b.38) of the Ponsonby edition of the Defence" (London, 1595)] http://www.luminarium.org/renascence-editions/defence.html (11.03.2019).

The 1599 Geneva Bible. The Bible Gateway, https://www.biblegateway.com/passage/? search $=1+$ Corinthians $+4 \% 3 \mathrm{~A} 10-12$ \&version $=\mathrm{GNV}(13.03 .2019)$. 